\title{
Movement of Juvenile Songbirds in Harvested Boreal Forest: Assessing Residency Time and Landscape Connectivity
}

\section{Déplacements des jeunes passereaux en forêt boréale aménagée : évaluation du temps de passage et de la connectivité du paysage}

\author{
$\underline{\text { Greg W. Mitchell }}^{1,2}, \underline{\text { Ian G. Warkentin }}^{3}$, and $\underline{\text { Philip D. Taylor }}^{1}$
}

\begin{abstract}
Little is known about juvenile songbird movement in response to timber harvest, particularly in the boreal forest. If clearcut land cover facilitates movement, the availability of resources may increase. However, if clearcut land cover impedes movement, important post-fledging resources may be rendered inaccessible. Using radio telemetry, we tested the hypothesis that regenerating clearcut land cover would affect the movement of recently independent Yellow-rumped Myrtle Warblers (Dendroica coronata coronata) and Blackpoll Warblers (Dendroica striata) differently than forested land cover owing to intrinsic differences in each land-cover type or in how they are perceived. We found that both species moved extensively before migration. We also found that Blackpoll Warblers were quick to exit local areas composed of clearcut land cover and that both species were quick to exit neighborhoods composed of large proportions of clearcut land cover. However, if individuals encountered clearcut land cover when exiting the neighborhood, movement rate was slowed. Effectively, residency time decreased in clearcut neighborhoods and landscape connectivity was impeded by clearcut land cover. Our results suggest that clearcut land cover may represent low-quality habitat for both species during the post-fledging period. Further research is needed to determine if changes in movement behavior associated with landscape structure affect individual condition and higher-level ecological processes.
\end{abstract}

RÉSUMÉ. On connait peu de choses en ce qui concerne le déplacement des jeunes passereaux suite à la récolte forestière, particulièrement en forêt boréale. Dans le cas où un parterre de coupe à blanc favorise les déplacements, l'accessibilité aux ressources peut augmenter. Toutefois, si le parterre de coupe à blanc nuit aux déplacements, des ressources importantes après l'envol pourraient devenir inaccessibles. À l'aide de la radio-télémétrie, nous avons testé l'hypothèse selon laquelle l'effet d'un parterre de coupe à blanc en régénération est différent de celui d'un couvert forestier sur le déplacement de Parulines à croupion jaune (Dendroica coronata coronata) et de Parulines rayées (Dendroica striata) ayant tout juste acquis leur indépendance, à cause des différences intrinsèques relatives à chaque type de couvert ou de la perception qu'en ont les oiseaux. Nous avons trouvé que les deux espèces de paruline se déplacent considérablement avant la migration. Nous avons également constaté que la Paruline rayée quittait rapidement les secteurs locaux constitués de parterres de coupe à blanc et que les deux espèces quittaient rapidement les secteurs voisins qui comportaient une grande proportion de parterre de coupe à blanc. Cependant, si un individu atteignait un parterre de coupe à blanc au moment de quitter le voisinage, son taux de déplacement était ralenti. Dans les faits, le temps de passage diminuait dans le voisinage des parterres de coupe à blanc et ces derniers réduisaient la connectivité du paysage. Nos résultats donnent à penser que les parterres de coupe à blanc représentent des milieux de faible qualité pour les deux espèces de paruline durant la période qui suit l'envol. De plus amples recherches sont nécessaires afin de déterminer si les changements au plan du comportement en déplacement selon la structure du paysage ont un effet sur la condition de l'individu et sur les processus écologiques généraux.

Key Words: boreal forest; clearcut forestry; juvenile songbirds; landscape connectivity; movement ecology; postfledging period

${ }^{1}$ Acadia University, Canada, ${ }^{2}$ University of Guelph, ${ }^{3}$ Memorial University of Newfoundland

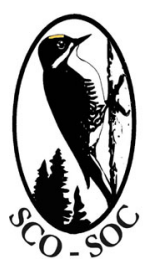

Sponsored by the Society of Canadian Ornithologists and Bird Studies Canada

Parrainée par la Société des ornithologistes du Canada et Études d'oiseaux Canada

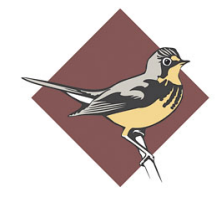

BIRD STUDIES CANADA 


\section{INTRODUCTION}

The post-fledging period, from nest departure by recently hatched birds through to autumn migration, presents many challenges to individual survival. It is a time of extensive landscape-level movement (e. g., Anders et al. 1998, Vega Rivera et al. 1998, Bayne and Hobson 2001, Kershner et al. 2004) and considerable energetic constraint (Sullivan 1989, Weathers and Sullivan 1989). Individuals must balance their time between (1) locating and acquiring energy for metabolic maintenance, thermal regulation, pre-basic molt, and migratory fat loading (Sullivan 1988, Weathers and Sullivan 1989, Anders et al. 1998, Vega Rivera et al. 1998) and (2) avoiding predators (Sullivan 1988, Kershner et al. 2004). Despite the importance of movement for locating and accessing resources, we have little idea how changes to landscape structure by forest management affect movement during this time, particularly in the boreal forest. If clearcut land cover facilitates movement, the availability of important post-fledging resources may increase. Conversely, if clearcut land cover impedes movement, important post-fledging resources may be rendered inaccessible.

To date, most research investigating songbirds during the post-fledging period has taken place in temperate deciduous forests (e.g., Vega Rivera et al. 1998, Pagen et al. 2000, Marshall et al. 2003, Vitz and Rodewald 2007). These studies suggest that individuals readily inhabit patches of regenerating clearcut land cover (Pagen et al. 2000, Marshall et al. 2003, Vitz and Rodewald 2007), likely owing to the relative availability of both food and shelter (Anders et al. 1998, Vega Rivera et al. 1998). However, given lower soil productivity and rates of succession at more northern latitudes, we might not expect to observe similar patterns in the boreal forest. Indeed, netting and playback experiments indicate that songbirds are reluctant to traverse clearcut areas in the boreal forest during the post-fledging period (Machtans et al. 1996, Desrochers and Hannon 1997, Robichaud et al. 2002), suggesting that clearcut land cover may be perceived as low quality or risky. Thus, a more direct assessment of movement with respect to clearcut land cover in the boreal forest is needed to understand more thoroughly songbird sensitivity to landscape structure in this region.
Movement is a quantifiable behavior dependent on both an organism's internal state and its response to its external environment (McIntyre and Wiens 1999, Nathan et al. 2008). Therefore, movement behavior can be used to evaluate sensitivity to landscape structure (e.g., Wiens et al. 1997, Jonsen and Taylor 2000), with movement rate representing one measure of this behavior. For example, movement rate can be used to evaluate residency time within an area or patch (sensu Bélisle 2005) or exit time, where slowed movement rates may be indicative of high resource availability or low predation risk (e.g., Zollner and Lima 2005). Alternatively, movement rate can also be used to evaluate landscape connectivity, i.e., the degree to which landscape structure facilitates or impedes movement (sensu Taylor et al. 1993, Taylor et al. 2006). In this context, slowed movement rates along a trajectory between two points may either reflect a reluctance to traverse matrix habitat or matrix habitat boundaries (e.g., Bélisle and St. Clair 2001, Harris and Reed 2002) or movement through highquality matrix habitat (Jonsen and Taylor 2000, Taylor et al. 2006). Together, both measurements complement each other, in that the former provides an assessment of sensitivity to landscape structure averaged over a defined area, whereas the latter provides an assessment of sensitivity to landscape structure for a given movement trajectory.

We used radio telemetry to track the movements of recently fledged Yellow-rumped (Myrtle) Warblers (Dendroica coronata coronata) and Blackpoll Warblers (D. striata) through landscapes composed of varying amounts of clearcut land cover in western Newfoundland, Canada. We hypothesized that regenerating clearcut land cover would affect juvenile songbird movement differently than forested land cover, owing to either unmeasured intrinsic differences between the two land-cover types (e.g., differences in resource availability, predation risk, etc.) or differences in how each landcover type is perceived. We predicted that movement rates would vary with the amount of clearcut land cover (1) at multiple spatial scales surrounding an individual's location and (2) along an individual's movement path. Our results provide new insights into juvenile songbird movement with respect to clearcut land cover in the boreal forest, and provide a simple framework for investigating the effects of landscape structure using individualbased tracking data. 


\section{METHODS}

\section{Study Species}

Yellow-rumped and Blackpoll Warblers are small (13 g) insectivorous songbirds with similar breeding phenologies. The Myrtle subspecies of Yellowrumped Warbler breeds throughout temperate North America and winters in the eastern United States, Mexico, and Central America (Hunt and Flashpohler 1998). The Blackpoll Warbler breeds throughout the boreal forest, and winters in Bolivia, Peru, Columbia, Venezuela, Guyana, Suriname, and northwestern Brazil (Hunt and Eliason 1999). During the breeding period both species are commonly observed foraging in the canopies of mature conifer trees located in forest interior, riparian edge, forest edge, and to lesser extent, open habitats (Hunt and Flashpohler 1998, Hunt and Eliason 1999, Whitaker and Montevecchi 1999). Little is known about habitat associations for these two species during the post-fledging period.

\section{Study Area}

Research took place in northwestern Newfoundland, Canada (UTM 21N, WGS84, Easting: 0479000, Northing: 5515000; Fig. 1). This area is composed of old-growth forest interspersed with water courses, ponds, lakes, rocky outcrops, peatlands, patches of coniferous scrub, and patches of regenerating clearcut land cover (logged in 1999 and 2000). Clearcut areas comprise $6 \%$ of the landscape, are irregular in shape and size (20-100 ha), and at the time of the study, were characterized by abundant coarse woody debris and low densities of mature white birch (Betula papyrifera) and regenerating balsam fir (Abies balsamea). The region is characteristically cool and moist, and owing to reduced fire disturbance, forests are dominated by balsam fir (Thompson et al. 2003) with lesser amounts of black spruce (Picea mariana), white spruce ( $P$. glauca), and white birch (Damman 1983).

\section{Baseline Sampling}

During 2005, 26 Yellow-rumped and 25 Blackpoll Warblers were captured between 20 July and 05 August. During 2006, 22 Yellow-rumped and 23
Blackpoll Warblers were captured between 26 July and 07 August. All captures were part of a concurrent passive mist-netting study examining boreal songbird movement and demography (Whitaker et al. 2008). Upon capture, individuals were aged based on plumage criteria (Pyle 1997) and then fitted with a unique color-band combination (three bands), a numbered U.S. Fish and Wildlife Service aluminium leg band, and a 0.53-g transmitter (Holohil Systems Ltd., Carp, Ontario; model BD-2N, median battery life: $17 \mathrm{~d}$ ). Transmitters were affixed to birds using a modified harness design (Rappole and Tipton 1991) composed of elastic cotton thread and catgut suture material. The total weight of the harness and radio equaled $0.66 \mathrm{~g}$ (i.e., $5 \%$ of an individual's body mass). Radio tagging was initiated when family groups began to break apart and juveniles began to disperse as indicated by increased juvenile capture rates in the concurrent netting study. All procedures were approved by the Animal Care Committee of Acadia University in accordance with Canadian Council on Animal Care guidelines, and adhered to the legal requirements of the Canadian Wildlife Service.

\section{Radio Tracking}

Tracking began $24 \mathrm{~h}$ following radio attachment. Individuals were located by homing on foot (following a signal up to and observing an individual) as well as through four aerial telemetry flights (median number of locations per individual: 7; range: 2-20; Yellow-rumped Warbler total: 330 and Blackpoll Warbler total: 301). For all tracking, we used TR-4 Receivers (Telonics Inc., Mesa, Arizona, USA) and two- (Telonics Inc., Mesa, Arizona, USA) or three-element (Advanced Telemetry Systems, Isanti, Minnesota, USA) handheld antennae. Locations were obtained opportunistically between 6:00 and 20:00 h. We attempted to locate individuals every 1-3 d, however owing to the spatial extent of movement, there were more than $3 \mathrm{~d}$ between sequential locations for $10 \%$ of all observations (median number of $\mathrm{d}$ between locations: 1.26 ; range: 0.60 12.91). Individual locations were recorded using Garmin eTrex Venture ${ }^{\circledR}$ Global Positioning System units (Olathe, Kansas, USA) set to record UTM coordinates (WGS 84, zone $21 \mathrm{~N}$ ). When an individual's signal was lost (potentially predation, migration commencement, or radio failure), the 
Fig. 1. Digital elevation model and locations (white circles) of study sites in northwestern Newfoundland. Study sites are the locations where birds were initially captured and fitted with radio transmitters. Dark green and brown areas represent high and low elevation habitat, respectively. Red areas represent clearcut land cover. Blue areas represent lakes and first- and second-order rivers. North is located at the top of the map (depicted by the white arrow).

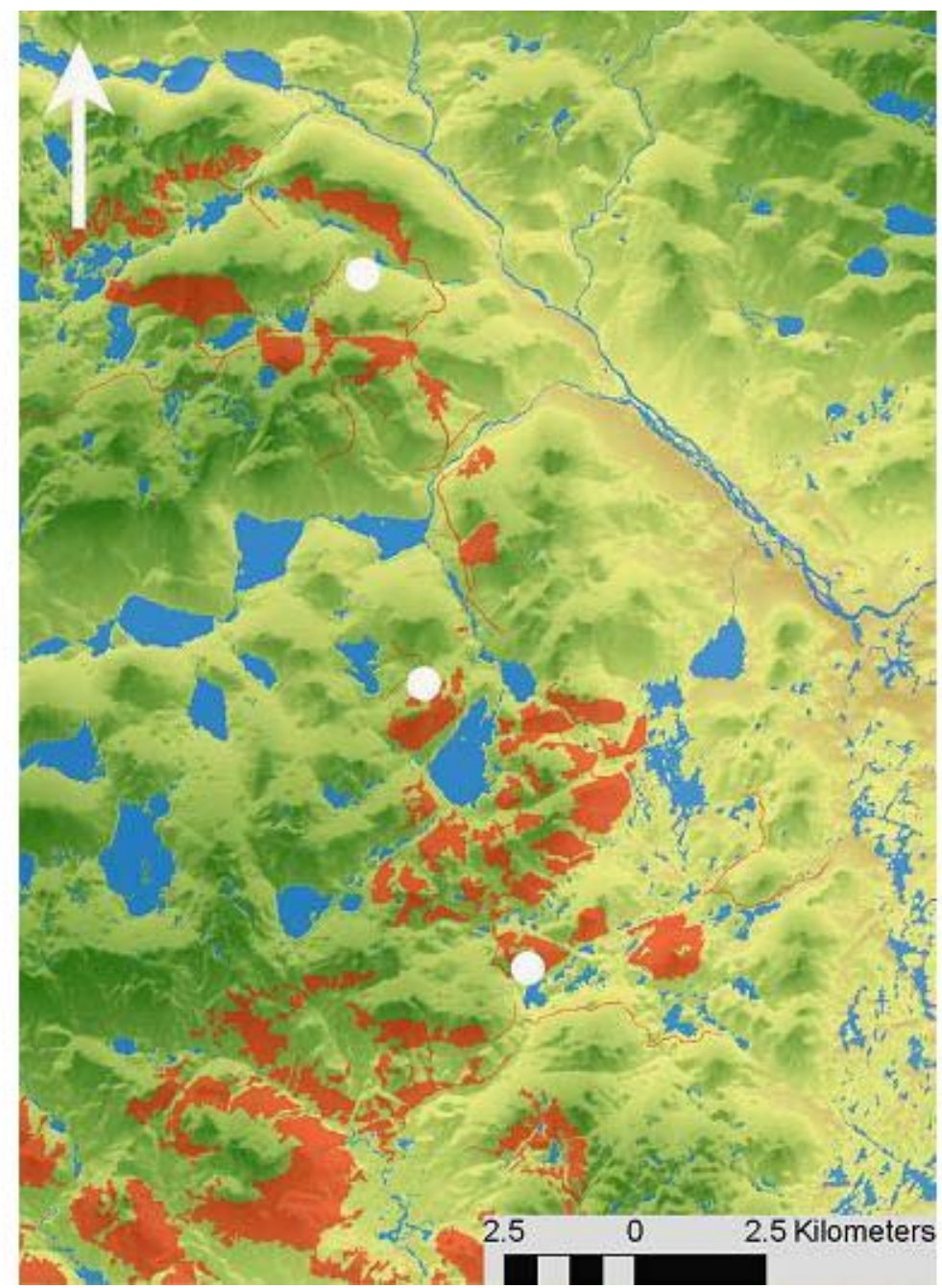

study area was surveyed by triangulation from mountaintops every 2-3 $\mathrm{d}$ for the remainder of the study period. A $660 \mathrm{~km}^{2}$ area encompassing our study site was also searched during each aerial telemetry flight. Tracking took place until 25 August and 27 August in 2005 and 2006, respectively.

\section{Model Terms}

We used movement RATE (words in capitals refer to model terms) as our response in all models. RATE was measured as the distance $(\mathrm{m})$ between successive locations, divided by the number of $\mathrm{d}$ between each location. Quantifying movement in this manner has the potential to underestimate movement rate as the number of $d$ between locations 
increases. If this were the case, we would predict a negative relationship between movement rate and the time between locations. We tested this prediction using linear mixed-effect models for both species, with individual as a random effect. For Yellow-rumped Warblers we did not detect an effect of $d$ between locations on movement rate $(P>0.05)$, however, for Blackpoll Warblers, we found a negative relationship $(P<0.05)$. To ensure this did not bias parameter estimates for Blackpoll Warblers, we refit of our final model to a subset of the data for which there was only $1 \mathrm{~d}$ between sequential locations. This procedure did not affect the sign, magnitude, or significance of parameter estimates.

To assess residency time with respect to clearcut land cover, we modeled movement RATE as a function of LOCAL land-cover type and the proportion of harvested land cover at the NEIGHBORHOOD and LANDSCAPE scales (Table 1). LOCAL land cover was assessed within a 5-m radius of the location where an individual was observed, and was classified as either CLEARCUT, FOREST, or PEATLAND based on the predominant feature. For those locations determined during aerial telemetry flights, LOCAL land cover was estimated from forest inventory maps. Circular buffers centered on observed locations, each with a radius of $115 \mathrm{~m}$ or $1250 \mathrm{~m}$, respectively, defined the NEIGHBORHOOD and LANDSCAPE scales (Fig. 2 ). Buffers of this size were chosen because they closely mirror the breeding territory and homerange extent of similar-sized warblers in our study region (Leonard et al. 2008), and thus approximate the likely spatial scales at which individuals are most frequently interacting with their environment.

To assess landscape connectivity with respect to clearcut land cover we modeled movement RATE as a function of the proportion of clearcut land cover within a 330-m buffer (CUT_PATH; Table 1, Fig. 2) centered on a line connecting sequential locations. This term was included in the same models described above for residency time. A width of $330 \mathrm{~m}$ was chosen because it encompasses the median movement distance (i.e., $312 \mathrm{~m}$ ) covered by birds when there was only $1 \mathrm{~d}$ between successive locations, suggesting that individuals could have easily encountered all clearcut land cover contained within the buffer. All land-cover variables, except LOCAL land cover as described above, were measured in ArcGIS 9.1 (Environmental Science Research Institute 2005; Redlands, California,
USA) using 1:15 840 forest inventory maps produced by the Newfoundland and Labrador Department of Natural Resources (last updated in 2000).

To account for variation in movement associated with social behavior and time, we also included FAMILY, DATE, and YEAR predictors in our models (Table 1). FAMILY represents a binomial variable indicating whether an individual was with or not with their family at the time of location. An individual was described as being with its family if it exhibited food-begging behavior toward conspecifics, if it was observed being fed by an adult, or if it was observed with a known radiotagged sibling. The last recorded family groups were observed on 8 August 2005 and 2 August 2006.

\section{Model Structure}

All modeling was completed in $\mathrm{R} 2.8 .0$ ( $\mathrm{R}$ Development Core Team 2008). To test our hypothesis, we used linear mixed-effects models with restricted maximum likelihood estimates. Random effects were included to account for repeated measures among individuals. We also included order 1 autoregressive models within each mixed-effects model to account for serial correlation among sequential measures of movement rate within an individual (Pinheiro and Bates 2000). Models were fit separately for each species.

Before model fitting, we assessed all possible curvilinear relationships between RATE and predictors using scatter plots fitted with locally weighted regression lines. Based on the results of this assessment, we included curvilinear terms for DATE and LANDSCAPE in the global models for Yellow-rumped and Blackpoll Warblers, respectively. Also before model fitting, we assessed correlation between predictors using the model covariance matrix; in all cases, variables were found not to be highly correlated (i.e., $r<0.7$ ). Global and final model fit was visually assessed using standard residual plots for both main and random effects.

Because global models containing all fixed effects and two-way interactions would have contained too many parameters, we used a four-step modeling approach; each model was composed of predictors and all possible two-way interactions. First, a natural history model was fit containing FAMILY, 
Table 1. Model terms used in movement-rate models to assess residency time and landscape connectivity.

\author{
Continuous Predictors \\ CUT_PATH; proportion of clearcut land cover within a 330-m buffer centered on a \\ line connecting successive locations \\ DATE; ordinal date, $200=20$ July \\ LANDSCAPE; proportion of clearcut land cover in circular area defined by a radius \\ of $1250 \mathrm{~m}$ \\ NEIGHBORHOOD; proportion of clearcut land cover in circular area defined by a \\ radius of $115 \mathrm{~m}$ \\ Categorical Predictors \\ FAMILY; 2-levels: YES in a family group or No, not in a family group \\ LOCAL; local land-cover type, three levels: CLEARCUT, FOREST, PEATLAND \\ YEAR; two levels: 2005 or 2006
}

DATE, and YEAR as explanatory variables. Second, a landscape model was fit with LOCAL land-cover type, NEIGHBORHOOD, LANDSCAPE, and CUT_PATH as predictors. Third, an interaction model was fit to the data, specifying all two-way interactions between variables from the natural history and landscape models, except those previously explored. Following this, the main effects from the best-fit models from each of the above modeling stages were combined, and again, all two-way interactions were explored. We could not fit an interaction between CUT_PATH and LANDSCAPE for Blackpoll Warblers because the model would not converge on a reasonable parameter estimate.

\section{Data Censoring}

During 2005, three pairs of Yellow-rumped and two pairs of Blackpoll Warbler siblings, and during 2006, one pair of Yellow-rumped Warbler siblings (i.e., captured in family groups) were equipped with transmitters. To maintain independence of data, the locations for one individual of a pair (i.e., the one followed for a shorter total amount of time) were removed from the analyzed data set. This resulted in final sample sizes of 44 and 46 individuals for Yellow-rumped and Blackpoll Warblers, respectively.

\section{RESULTS}

\section{Magnitude of Movement}

Median movement distance between successive locations for Yellow-rumped Warblers was $501 \mathrm{~m}$ (1.2 $\mathrm{d}$ between locations). The minimum and maximum distances between successive locations were 23 and $16318 \mathrm{~m}$ (1.0 and $4.0 \mathrm{~d}$ between locations), respectively (Fig. 3). For Blackpoll Warblers, median movement distance between successive locations was $423 \mathrm{~m}$ (1.1 d between locations), and the minimum and maximum distances between successive locations were 3 and $9078 \mathrm{~m}$ (0.7 d and $1.9 \mathrm{~d}$ between locations), respectively (Fig. 3). Median movement rate for Yellow-rumped Warblers was 353 m/d (range: 246154 m/d; Fig. 4); for Blackpoll Warblers, median movement rate was $303 \mathrm{~m} / \mathrm{d}$ (range: $4-7380 \mathrm{~m} / \mathrm{d}$; Fig. 4). 
Fig. 2. Digital elevation model and movement track for a Blackpoll Warbler originally captured at the southern-most study site. White circles represent individual locations at specific dates. Sequential locations have been connected using black lines. Green and yellow areas represent high and low elevation habitat, respectively. Red areas represent clearcut land cover and blue areas represent lakes as well as first- and second-order rivers. The small and large purple circles buffering points at 15 August and 18 August represent examples of neighborhood and landscape buffers, respectively. The gray rectangle located between locations at 09 August and 15 August is an example of a buffer that was used to quantify clearcut land cover between sequential locations for the assessment of landscape connectivity. North is located at the top of the map (depicted by the white arrow).

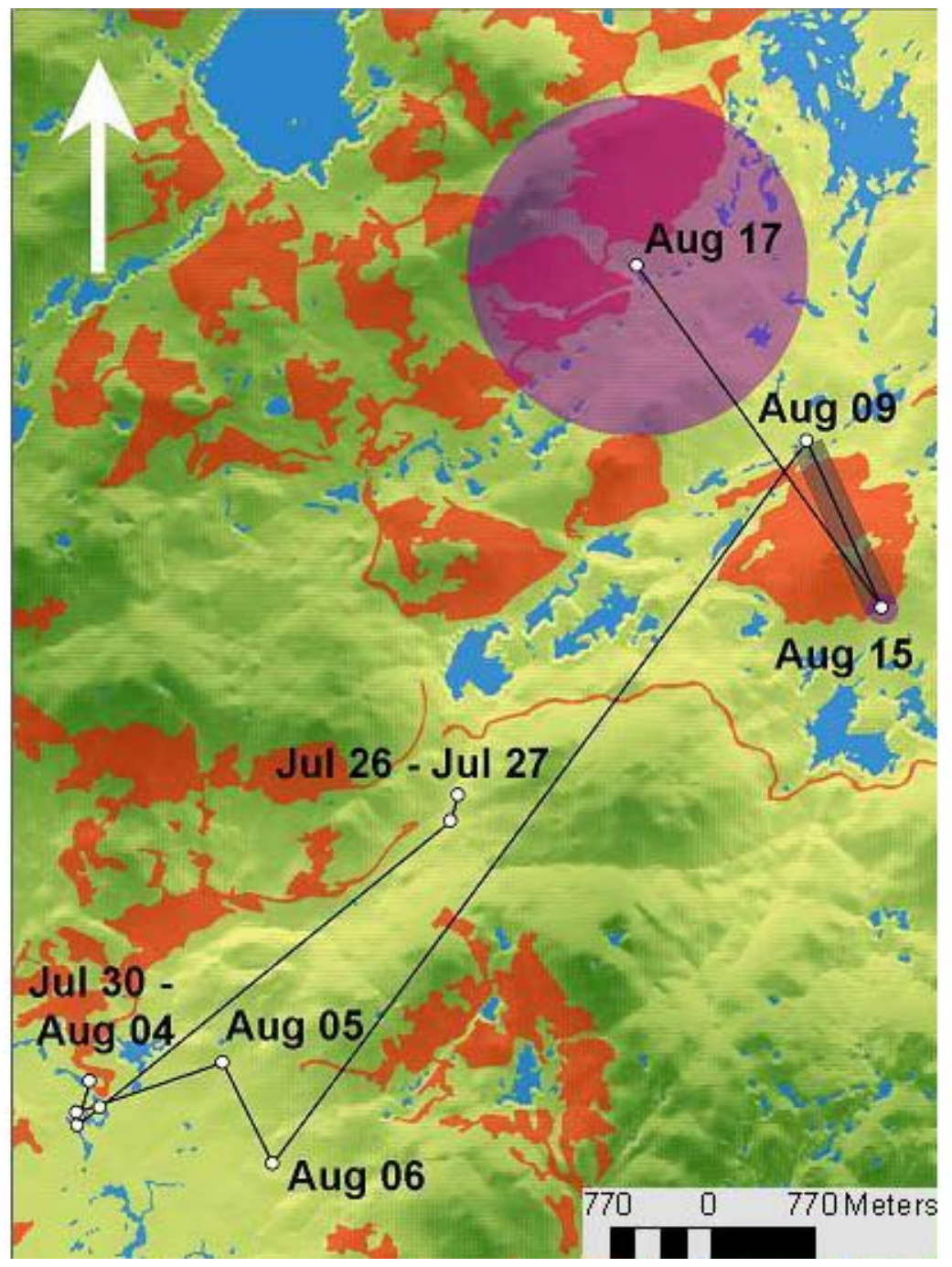


Fig. 3. Density and rug plots illustrating movement distance distributions for (A) Blackpoll and (B) Yellow-rumped Warblers. Density represents the relative proportion of observations for a given movement distance.

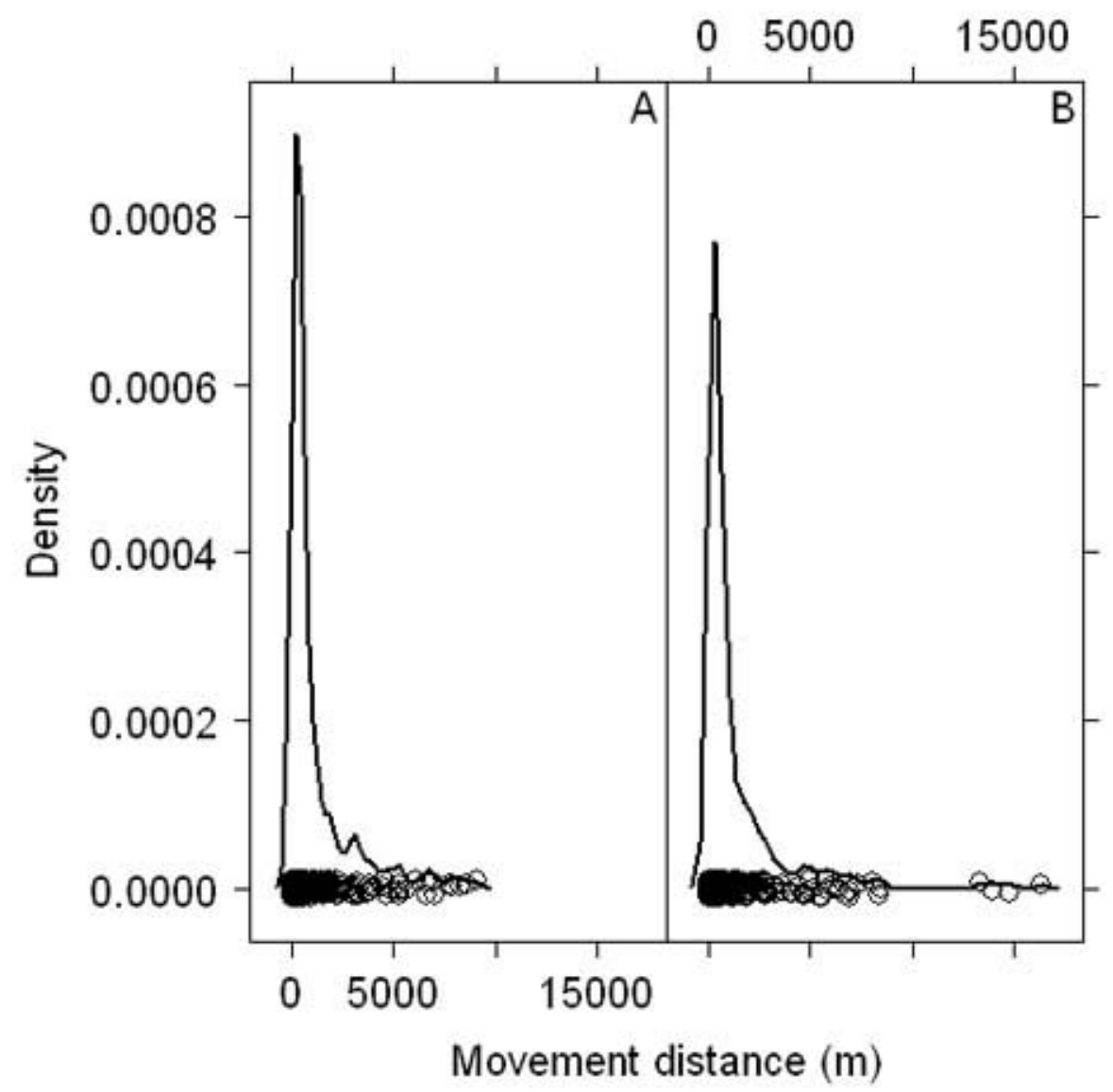

\section{Assessment of Residency Time and Landscape Connectivity}

For Blackpoll Warblers, movement rate was higher when moving away from local areas composed of clearcut land cover, relative to forested areas $(t$ $=-3.4$, df $=201, P<0.01$; Table 2, Fig. 5). Also, for both species there was a significant interaction between the proportion of clearcut land cover along a movement path and the proportion of clearcut land cover at the neighborhood scale (Yellow-rumped Warbler: $t=-2.4$, df $=235, P=0.02$; Blackpoll Warbler: $t=-3.5$, df $=201, P<0.01$; Table 2, Figs. 6 and 7 ). Specifically, movement rate increased (and residency time decreased) linearly as the proportion of clearcut land cover increased, but if there was a high proportion of clearcut land cover along the movement path used to exit the neighborhood, movement rate was reduced (connectivity was impeded). For both species, movement rate was also affected by date; for Yellow-rumped Warblers, this relationship was curvilinear and for Blackpoll Warblers, rate increased linearly with date $(t=-2.4$, $\mathrm{df}=235, P=0.02$ and $t=4.5$, df $=201, P<0.01$, respectively; Table 2, Fig. 8). We did not detect an effect for family group, year, or proportion of clearcut land cover at the landscape scale for either species. 
Fig. 4. Density and rug plots illustrating movement rate distributions for (A) Blackpoll and (B) Yellowrumped Warblers. Density represents the relative proportion of observations for a given movement rate.

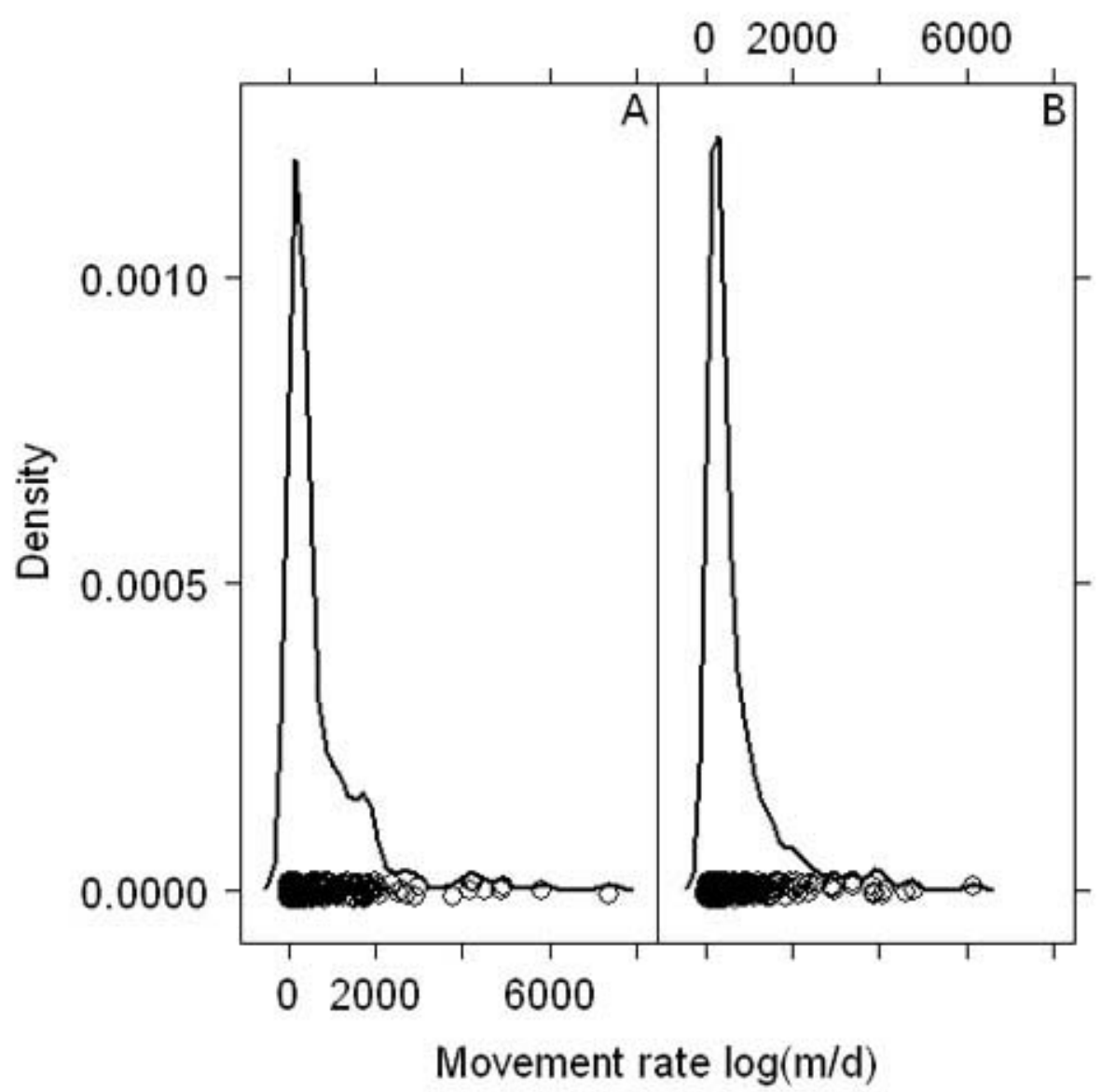

\section{DISCUSSION}

We show that juveniles of two closely related songbird species moved extensively $($ scale $=\mathrm{km})$ before their autumn migration (e.g., Fig. 2) and that movement rate was influenced by clearcut land cover. Specifically, for Blackpoll Warblers, residency time (sensu Bélisle 2005) decreased in local areas composed of clearcut land cover relative to forested land cover, and for both species, residency time decreased with the proportion of clearcut land cover at the neighborhood scale. However, if individuals encountered a high proportion of clearcut land cover as they exited a neighborhood, landscape connectivity was impeded (sensu Taylor et al. 1993, Taylor et al. 2006).
Effectively, individuals were quick to leave heavily harvested areas, reducing their residency time, but were slowed as clearcut land cover was encountered upon moving away.

Our data are consistent with other studies (e.g., Anders et al. 1998, Vega Rivera et al. 1998) showing the post-fledging period to be a time of extensive landscape-level movement. Individuals are moving at a scale between the home-range size of adult songbirds during the breeding period (e.g., Leonard et al. 2008) and current estimates of between-year dispersal distances (e.g., Toms et al. 2004, Tittler et al. 2006). Although the extent of these movements likely has important implications for locating and securing resources, it also suggests that individuals 
Table 2. Parameter estimates for significant predictors from best-fit final linear mixed-effects models used to explain juvenile Yellow-rumped and Blackpoll Warbler movement rates.

\begin{tabular}{|c|c|c|c|c|c|}
\hline & DF & $\mathrm{b}$ & SE & $t$ value & $\operatorname{Pr}(t)$ \\
\hline \multicolumn{6}{|c|}{ Yellow-rumped Warblers } \\
\hline Intercept & 235 & -136.682 & 56.986 & -2.398 & 0.017 \\
\hline DATE & 235 & 1.281 & 0.519 & 2.467 & 0.014 \\
\hline DATE $^{2}$ & 235 & -0.002 & 0.001 & -2.431 & 0.016 \\
\hline $\mathrm{NEIGH}^{\dagger}$ & 235 & 1.040 & 0.356 & 2.926 & 0.003 \\
\hline CUT_P & 235 & 0.738 & 0.829 & 0.891 & 0.374 \\
\hline NEIGH X CUT_P & 235 & -3.378 & 1.383 & -2.433 & 0.015 \\
\hline \multicolumn{6}{|l|}{ Blackpoll Warblers } \\
\hline Intercept & 201 & -10.923 & 3.898 & -2.802 & 0.006 \\
\hline DATE & 201 & 0.079 & 0.019 & 4.455 & $<0.001$ \\
\hline LOCAL_FOR $^{\S}$ & 201 & -0.769 & 0.229 & -3.365 & 0.001 \\
\hline LOCAL_PEAT $^{\mid}$ & 201 & -0.151 & 0.286 & -0.527 & 0.599 \\
\hline $\mathrm{NEIGH}^{\dagger}$ & 201 & 0.937 & 0.386 & 2.429 & 0.016 \\
\hline CUT_P & 201 & 1.052 & 0.688 & 1.529 & 0.128 \\
\hline NEIGH X CUT_P & 201 & -3.573 & 1.012 & -3.532 & $<0.001$ \\
\hline
\end{tabular}

Notes:

$\uparrow$; NEIGH; NEIGHBORHOOD

\#; CUT_P; CUT_PATH

§; LOCALLFOR: LOCAL land cover, FOREST; reference level is CLEARCUT

|; LOCAL_PEAT: LOCAL land cover, PEATLAND; reference level is CLEARCUT

$\mathrm{X}$; indicates interaction

2 ; indicates quadratic terms

could be affected by land-use practices located some distance away from their natal territories. For example, if an individual moves to a heavily harvested area, but is reluctant to traverse clearcut land cover (see Machtans et al. 1996, Desrochers and Hannon 1997, Robichaud et al. 2002), excess energy may be expended trying to circumnavigate clearcut areas. Alternatively, if movement is impeded, an individual may fail to locate important resources embedded in the harvested matrix. In this context, post-fledging movement may represent a critical link between broader landscape structure and local population dynamics, such as survivorship and recruitment.

Movement behavior can provide important insights into what organisms know about and how they perceive their environment (Lima and Zollner 1996, 
Fig. 5. Box plots illustrating differences in movement rate residuals for Blackpoll Warblers moving away from local areas composed of forest, clearcut, and peatland land-cover types. The horizontal bar in the middle of each box (between the notches) represents the median residual value for each category. The bottom and top boxes below and above the median line represent the 25 th and 75 th percentiles of the data, respectively. The whiskers illustrate the minimum and maximum values of the residuals not considered to be outliers. The circles located outside the whiskers of the clearcut box represent potential outlying values.

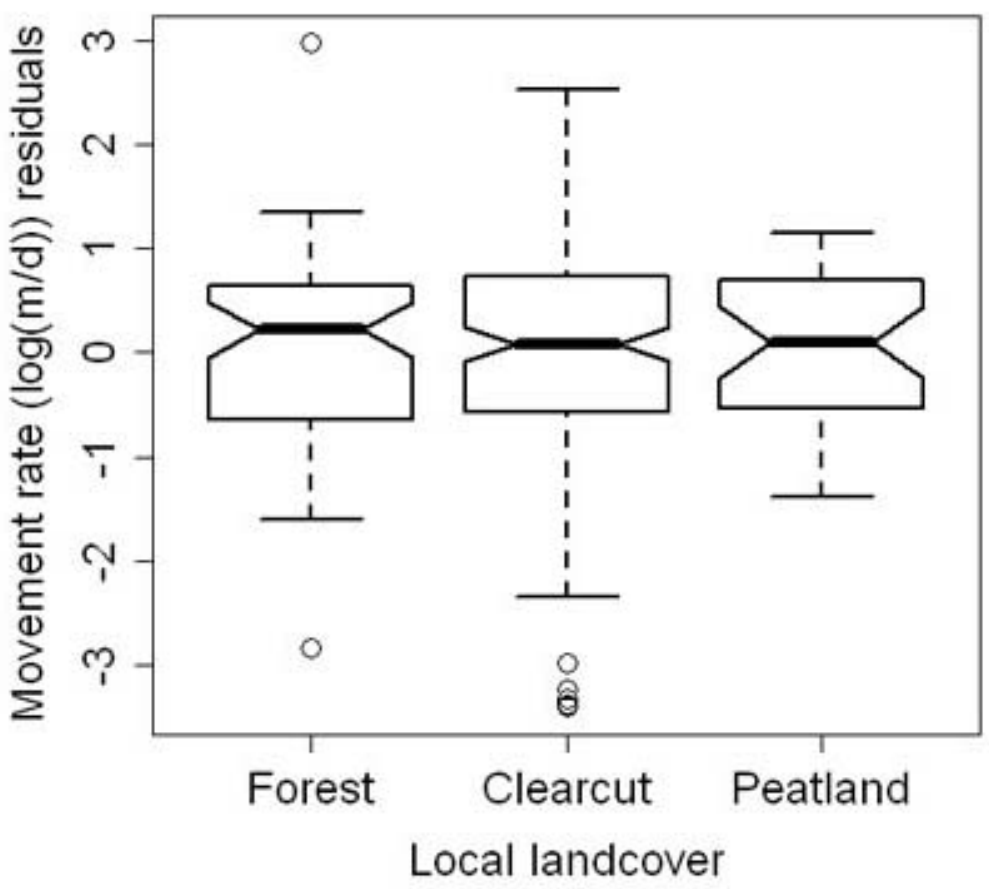

Nathan et al. 2008). Theory predicts that individuals should quickly exit from areas that provide few resources, especially if the likelihood of finding better habitat is high (e.g., Wiens 2001, Berggren et al. 2002, Bélisle 2005, Zollner and Lima 2005, Chin and Taylor 2009). We show that juvenile Blackpoll Warblers were quick to leave local areas composed of clearcut land cover, and that both Yellow-rumped and Blackpoll Warblers were quick to leave heavily clearcut neighborhoods. These observations are similar to results we found in a separate analysis where both species were less likely to select neighborhoods composed of high amounts of clearcut land cover relative to neighborhoods with low amounts (Mitchell et al., unpublished manuscript). Together, these findings and others (e. g., Machtans et al. 1996, Desrochers and Hannon 1997, Robichaud et al. 2002) suggest that clearcut land cover represents low-quality habitat. For example, clearcuts may support fewer or smaller invertebrates (Burke and Nol 1998, Zanette et al. 2000, Kilgo 2005), offer limited shelter from predators (Mitchell et al., unpublished manuscript), support higher predator abundances, or be perceived as being more risky relative to forested habitat (Harris and Reed 2002). Further research is needed to determine which of these hypotheses best explains our observed movement patterns.

As discussed above, we found that individuals were sensitive to the amount of clearcut land cover surrounding a given location. However, movement behavior can also be influenced by the landscape structure encountered while advancing along a trajectory. Our observed negative relationship between the proportion of clearcut land cover along 
Fig. 6. Scatter-plot illustrating movement rate interaction between the proportion of clearcut land cover at the neighborhood scale and the proportion of clearcut land cover along an individual's movement path for Yellow-rumped Warblers. (A) $0-35 \%$ of buffer surrounding movement path composed of clearcut land cover. (B) $35-70 \%$ of buffer surrounding movement path composed of clearcut land cover. Trends illustrated with locally weighted regression lines.

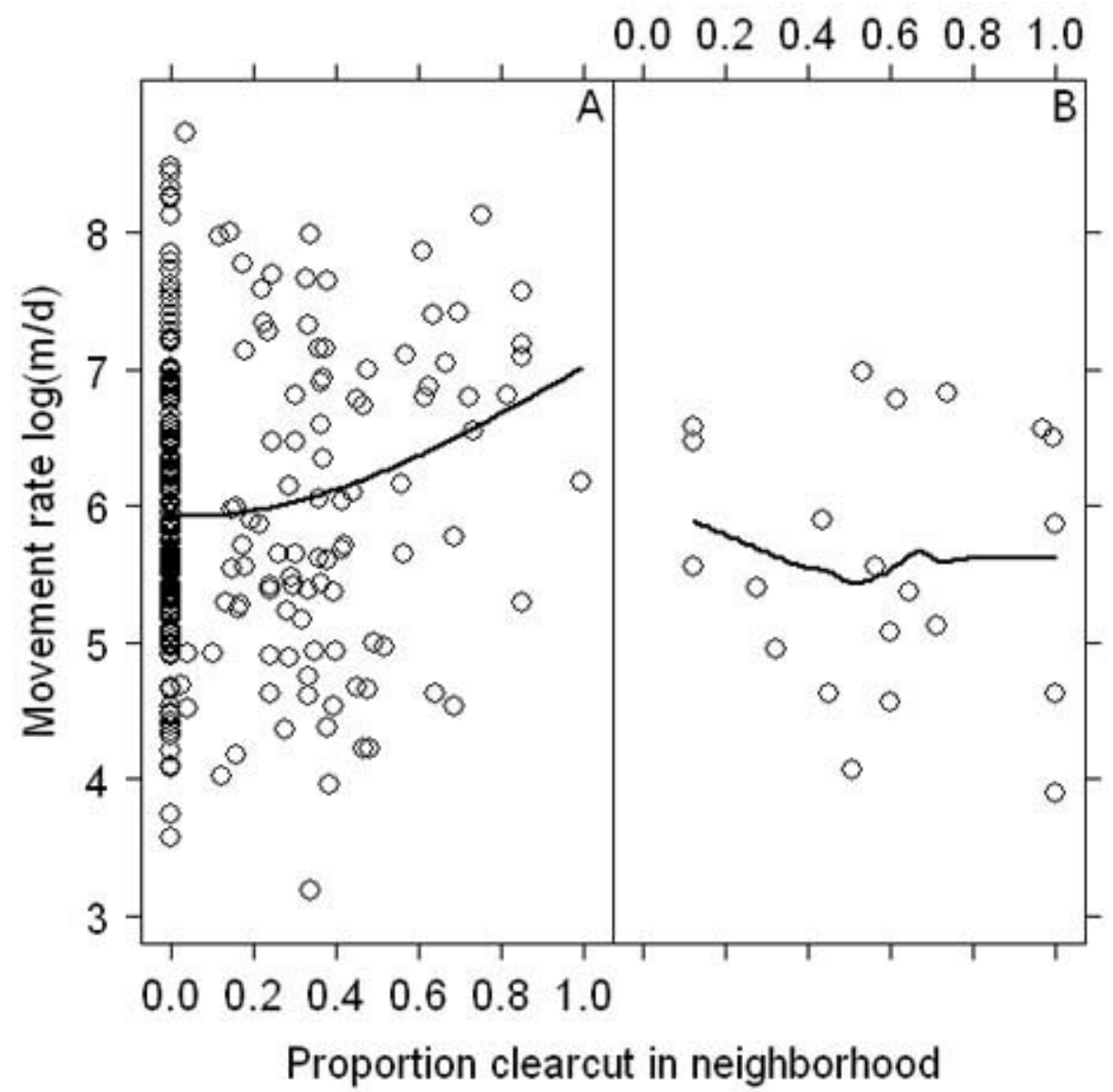

an individual's movement path and movement rate suggests that clearcut land cover impedes landscape connectivity. This observation may reflect one of several mechanisms, including slowed movement through high-quality matrix habitat (e.g., foraging; Jonsen and Taylor 2000, Zollner and Lima 2005), delays at forest-clearcut edges (Jonsen and Taylor 2000), or an increase in distance moved resulting from circumnavigation of clearcut areas (Desrochers and Hannon 1997). However, given our results regarding residency time and other literature suggesting that juveniles are reluctant to traverse clearcut land cover (Machtans et al. 1996, Desrochers and Hannon 1997, Robichaud et al. 2002), we suggest one of the latter two mechanisms is most likely. Interestingly, similar patterns of movement have also been observed during the breeding period (Bélisle and St. Clair 2001, Bélisle et al. 2001), suggesting that sensitivity to clearcut land cover may be conserved across age groups and periods of the annual cycle. Further research is needed to determine if this observed sensitivity affects individual condition as well as higher-level ecological processes (e.g., dispersal, recruitment). 
Fig. 7. Scatter-plot illustrating movement rate interaction between the proportion of clearcut land cover at the neighborhood scale and the proportion of clearcut land cover along an individual's movement path for Blackpoll Warblers. (A) $0-35 \%$ of buffer surrounding movement path composed of clearcut land cover. (B) $35-70 \%$ of buffer surrounding movement path composed of clearcut land cover. Trends illustrated with locally weighted regression lines.

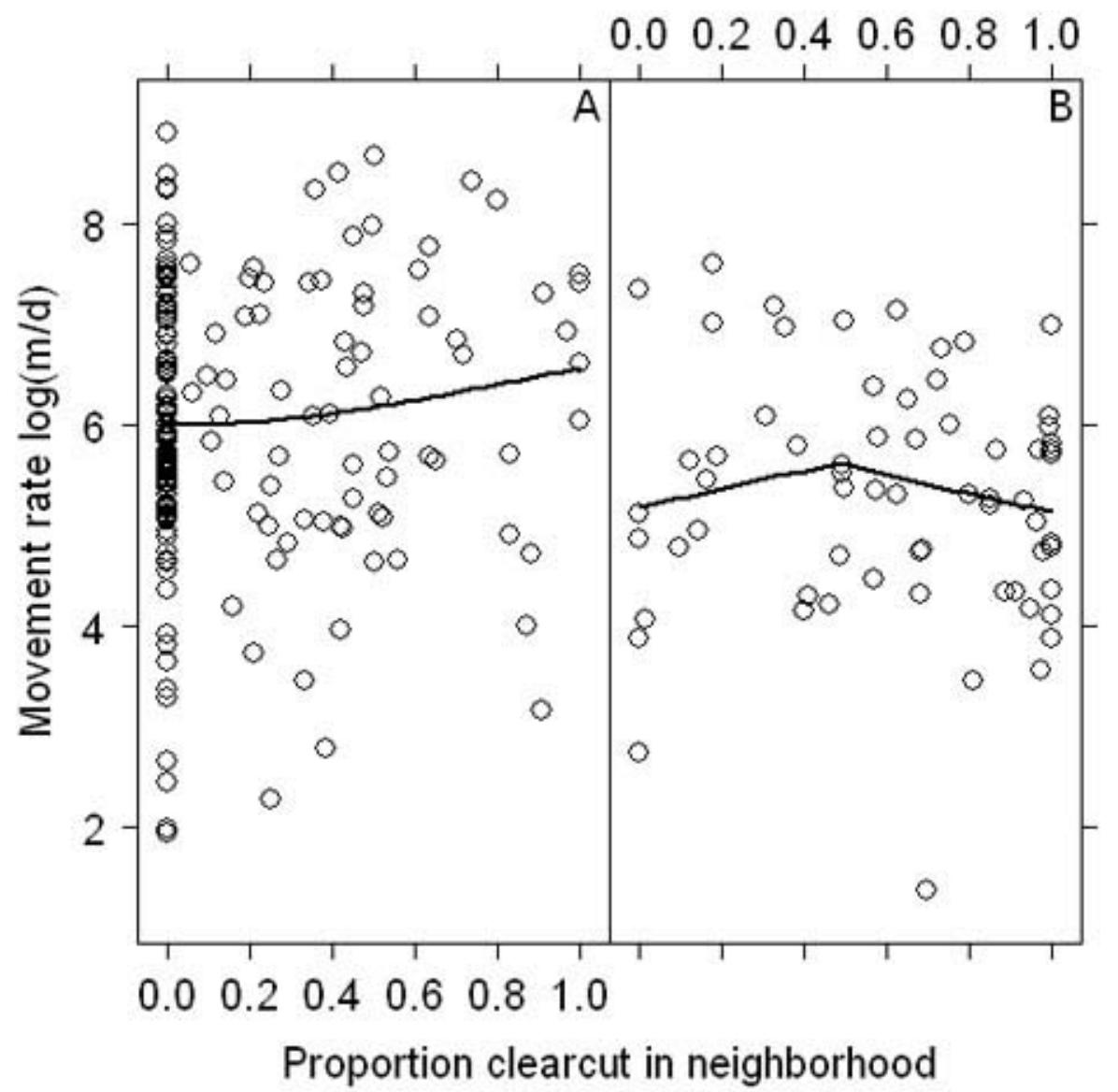

We examined movement with respect to landscape structure at three biologically relevant scales. This allowed us to assess potential differences in response to landscape structure across scales that could occur as a result of variation in the extent of different ecological processes (Wiens 1994, Wiens 2001, Chin and Taylor 2009). Although we did detect an effect of clearcut land cover on movement at two different spatial scales for Blackpoll Warblers, the outcome of the response was the same (e.g., fast exit times). This result suggests that individuals were affected in a similar manner, whether engaged in local foraging movements or movements between foraging patches. Curiously, other research in our study area also detected an effect of clearcut land cover at the landscape scale for Blackpoll Warblers with respect to occurrence and movement during the breeding period (Taylor and Krawchuk 2006, Leonard et al. 2008), a result we did not observe. This difference suggests that the scale of sensitivity may not be conserved across age groups, and that given the scope of movement during the post-fledging period, individuals may respond to clearcut landcover at spatial scales even larger than the landscape scale considered here. 
Fig. 8. Scatter-plot illustrating relationship between $\log$ (movement rate) and ordinal date for (A) Blackpoll and (B) Yellow-rumped Warblers. $200=20$ July. Trends illustrated with locally weighted regression lines.

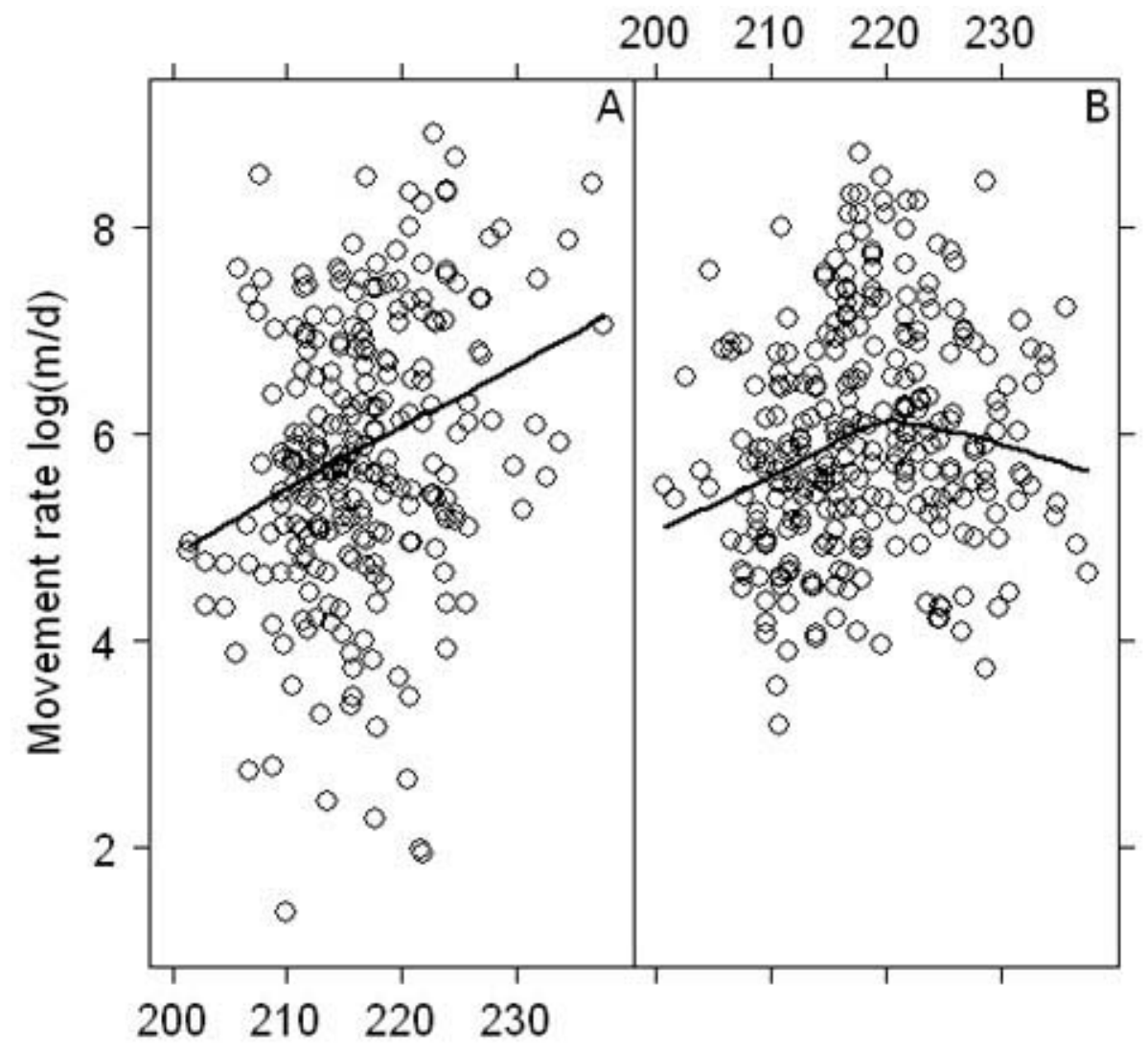

Ordinal date

\section{CONCLUSION}

We examined the hypothesis that clearcut land cover would affect juvenile songbird movement differently from forested land cover, owing to either unmeasured intrinsic differences between the two land-cover types (e.g., differences in resource availability, predation risk, etc.) or to differences in how each land-cover type is perceived. Our results suggest that clearcut land cover is of lower quality relative to forested land cover for juvenile songbirds in the boreal forest. Further research is needed to assess the exact ways in which clearcut land cover differs from forested land cover in order to determine why movement rate is faster when moving away from heavily harvested relative to non-harvested neighborhoods. Research is also needed to determine how fine-scale movement behaviors vary at matrix boundaries in order to determine the exact mechanism by which landscape structure impedes movement rate. Improved understanding of these aspects will enhance our ability to assess how changes in movement behavior may influence body condition and ultimately survival and fitness. 
Responses to this article can be read online at:

http://www.ace-eco.org/vol4/iss1/art5/responses/

\section{Acknowledgments:}

We thank D. M. Whitaker and T. D. Leonard for insightful comments regarding study design. $K$. $M$. Dalley, D. Gelenyse, B. Woodworth, P. Goulet, K. Horner, R. Demers, and K. Odom were invaluable in the field. Thanks to J. J. Nocera for comments on earlier drafts of this manuscript and to $S$. $P$. Flemming and T. W. Knight for logistic support. This research was funded by the Atlantic Cooperative Wildlife Research Network (P. D. T.), Parks Canada (P. D. T.) and the Natural Sciences and Engineering Research Council of Canada (P. D. T. and I. G. W.).

\section{LITERATURE CITED}

Anders, D. A., J. Faaborg, and F. R. Thompson, III. 1998. Post-fledging dispersal, habitat use, and home-range size of juvenile wood thrushes. Auk 115:349-358.

Bayne, E. M., and K. A. Hobson. 2001. Movement patterns of adult male ovenbirds during the postfledging period in fragmented and forested boreal landscapes. Condor 103:343-351.

Bélisle, M. 2005. Measuring landscape connectivity: the challenge of behavioral landscape ecology. Ecology 86:1988-1995.

Bélisle, M.,A. Desrochers, and M. J. Fortin. 2001. Influence of forest cover on the movements of forest birds: a homing experiment. Ecology 82:18931904.

Bélisle, M., and C. C. St. Clair. 2001. Cumulative effects of barriers on the movements of forest birds. Conservation Ecology 5: 9 [online] URL: http://ww w.consecol.org/vol5/iss2/art9/.

Berggren, А̊., B. Birath, and O. Kindvall. 2002. Effects of corridors and habitat edges on dispersal behavior, movement rates, and movement angles in Roesel's bush-cricket (Metrioptera roeseli). Conservation Biology 16:1562-1569.

Burke, D. M., and E. Nol. 1998. Influence of food abundance, nest-site habitat, and forest fragmentation on breeding ovenbirds. Auk 115:96-104

Chin, K. S., and P. D. Taylor. 2009. Interactive effects of distance and matrix on the movements of a peatland dragonfly. Ecography 32:1-8.

Damman, A. W. H. 1983. An ecological subdivision of the island of Newfoundland. Pages 163-206 in G. R. South, editor. Biogeography and ecology of the island of Newfoundland. Junk, Publishers, The Hague, The Netherlands.

Desrochers, A., and S. J. Hannon. 1997. Gap crossing decisions by forest songbirds during the post-fledging period. Conservation Biology 11:1204-1210.

Harris, R. J., and J. M. Reed. 2002. Behavioral barriers to non-migratory movements of birds. Annales Fennici Zoologici 39:275-290.

Hunt, P. D., and B. C. Eliason. 1999. Blackpoll Warbler (Dendroica striata). Number 431 in A. Poole and F. Gill, editors. The birds of North America. American Ornithologists' Union, Cornell Lab of Ornithology, and Academy of Natural Sciences, Philadelphia, Pennsylvania, USA.

Hunt, P. D., and J. Flashpohler. 1998. Yellowrumped Warbler (Dendroica coronota). Number 376 in A. Poole and F. Gill, editors. The birds of North America. American Ornithologists' Union, Cornell Lab of Ornithology, and Academy of Natural Sciences, Philadelphia, Pennsylvania, USA.

Jonsen, I. D., and P. D. Taylor. 2000. Fine-scale movement behaviors of calopterygid damselflies are influenced by landscape structure: an experimental manipulation. Oikos 88:553-562.

Kershner, E. L., J. W. Walk, and R. E. Warner. 2004. Post-fledging movements and survival of juvenile eastern meadowlarks (Sturnella magna) in Illinois. Auk 121:1146-1154.

Kilgo, J. C. 2005. Harvest-related edge effects on prey availability and foraging of hooded warblers in a bottomland hardwood forest. Condor 107:627636.

Leonard, T. D., P. D. Taylor, and I. G. Warkentin. 2008. Space use by songbirds in naturally patchy and harvested boreal forests. Condor 110:467-481. 
Lima, S. L., and P. A. Zollner. 1996. Towards a behavioral ecology of ecological landscapes. Trends in Ecology and Evolution 11:131-135.

Machtans, C. S., M. A. Villard, and S. J. Hannon. 1996. Use of riparian buffer strips as movement corridors by forest birds. Conservation Biology 10:1366-1379.

Marshall, M. R., J. A. DeCecco, A. B. Williams, G. A. Gale, and R. J. Cooper. 2003. Use of regenerating clearcuts by late-successional bird species and their young during the post-fledging period. Forest Ecology and Management 183:127135 .

McIntyre, N. E., and J. A. Wiens. 1999. Interactions between landscape structure and animal behavior: the roles of heterogeneously distributed resources and food deprivation on movement patterns. Landscape Ecology 14:437447.

Nathan, R., W. M. Getz, E. Revilla, M. Holyoak, R. Kadmon, D. Saltz, and P. E. Smouse. 2008. A movement ecology paradigm for unifying organismal movement research. Proceedings of the National Academy of Science 105:19052-19059.

Pagen, R. W., F. R. Thompson, III, and D. E. Burhans. 2000. Breeding and post-breeding habitat use by forest migrant songbirds in the Missouri Ozarks. Condor 102:738-747.

Pinheiro, J. C., and D. M. Bates. 2000. Theory and computational methods for linear mixed-effects models. Pages 57-96 in J. C. Pinheiro and D. M. Bates, editors. Statistics and computing: mixedeffects models in Sand S-Plus. Springer-Verlag Inc., New York, New York, USA.

Pyle, P. 1997. Identification guide to North American passerines. Slate Creek Press, Bolinas, California, USA.

Rappole, J. H., and A. R. Tipton. 1991. New harness design for attachment of radio transmitters to small passerines. Journal of Field Ornithology 62:335-337.

R Development Core Team. 2008. $R$ : a language and environment for statistical computing. Vienna: $\mathrm{R}$ Foundation for Statistical Computing. [online] http://www.R-project.org.
Robichaud, I., M. A. Villard, and C. S. Machtans. 2002. Effects of forest regeneration on songbird movements in a managed forest landscape of Alberta, Canada. Landscape Ecology 17:247-262.

Sullivan, K. A. 1988. Ontogeny of time budgets in yellow-eyed juncos: adaptation to ecological constraints. Ecology 69:118-124.

Sullivan, K. A. 1989. Predation and starvation: agespecific mortality in juvenile juncos (Junco phaenotus). Journal of Animal Ecology 58:275286.

Taylor, P. D., L. Fahrig, K. Henein, and G. Merriam. 1993. Connectivity is a vital element of landscape structure Oikos 68:571-573.

Taylor, P. D., L. Fahrig, and K. A. With. 2006. Landscape connectivity: back to the basics. Pages 29-43 in K. Crooks and M. A. Sanjayan, editors. Connectivity conservation. Cambridge University Press, New York, New York, USA.

Taylor, P. D., and M. A. Krawchuk. 2006. Scale and sensitivity of songbird occurrence to landscape structure in a harvested boreal forest. Avian Conservation and Ecology - écologie et conservation des oiseaux 1 (1): 5. [online] URL: http://www.ace-eco.org/vol1/iss1/art5/.

Thompson, I. D., D. J. Larson, and W. A. Montevecchi. 2003. Characterization of old "wet boreal" forests, with an example from balsam fir forests of western Newfoundland. Environmental Reviews 11:S23-S46.

Tittler, R., L. Fahrig, and M. A. Villard. 2006. Evidence of large-scale source-sink dynamics and long-distance dispersal among wood thrush populations. Ecology 87:3029-3036.

Toms, J. D., S. J. Hannon, and F. K. A. Schmiegelow. 2004. Population dynamics of songbirds in the boreal mixedwood forests of Alberta, Canada: estimating minimum and maximum extents of spatial population synchrony. Landscape Ecology 20:543-553.

Vega Rivera, J. H., J. H. Rappole, W. J. McShea, and J. A. Haas. 1998. Wood thrush postfledging movements and habitat use in northern Virginia. Condor 100:69-78. 
Vitz A. C., and A. D. Rodewald. 2007. Vegetative and fruit resources as determinants of habitat use by mature-forest birds during the post-breeding period. Auk 124:494-507.

Weathers, W. W., and K. A. Sullivan. 1989. Juvenile foraging proficiency, parental effort, and avian reproductive success. Ecological Monographs 59:223-246.

Wiens, J. A. 1994. Habitat fragmentation: island v landscape perspectives on bird conservation. Ibis 137:S97-S104.

Wiens, J. A. 2001. The landscape context of dispersal. Pages 96-109 in J. Clobert, E. Danchin, and A. A. Dhondt, editors. Dispersal. Oxford University Press, New York, New York, USA.

Wiens, J. A., R. L. Schooley, and R. D. Weeks. 1997. Patchy landscapes and animal movements: do beetles percolate? Oikos 78:257-264.

Whitaker, D. M., and W. A. Montevecchi. 1999. Breeding bird assemblages inhabiting riparian buffer strips in Newfoundland, Canada. Journal of Wildlife Management 63:167-179.

Whitaker, D. M., P. D. Taylor, and I. G. Warkentin. 2008. Survival of adult songbirds in boreal forest landscapes fragmented by clearcuts and natural openings. Avian Conservation and Ecology - écologie et conservation des oiseaux 3 (1): 5. [online] URL: http://www.ace-eco.org/vol3/ iss $1 /$ art5/.

Zanette, L., P. Doyle, and S. M. Tremont. 2000. Food shortage in small fragments: evidence from an area-sensitive passerine. Ecology 81:1654-1666.

Zollner, P. A., and S. L. Lima. 2005. Behavioral tradeoffs when dispersing across a patchy landscape. Oikos 108:219-230. 